Anna Jakubczak

Uniwersytet Technologiczno-Przyrodniczy w Bydgoszczy

\title{
Strategie greenwashing w wybranych sieciach handlowych w Polsce
}

\section{GREENWASHING STRATEGIES IN SELECTED RETAIL CHAINS IN POLAND}

\begin{abstract}
Problemem poruszonym $w$ artykule jest zjawisko greenwashing, które jest coraz częściej stosowane przez biznes, aby wprowadzić konsumentów w btędne przekonanie o wizerunku firmy lub produktu, jako przyjaznego środowisku naturalnemu. Celem artykulu jest analiza strategii greenwashing stosowanych przez sklepy dyskontowe $w$ ofercie produktów spożywczych i na ich opakowaniach przez producentów. Przeanalizowano kilkadziesiat produktów żywnościowych organicznych oraz "udajacych" organiczne $w$ dwóch popularnych sieciach dyskontowych $w$ Polsce. Analiza wyników potwierdza, że w wybranych sieciach stosuje się nieodpowiedzialnie społecznie praktyki sprzyjajace stosowaniu strategii greenwashing.
\end{abstract}

Słowa kluczowe: greenwasing, społeczna odpowiedzialność biznesu, społeczna odpowiedzialność konsumentów, green consumerism

\section{Wprowadzenie i metoda}

Zjawisko zwane "Greenwashing" jest definiowane w marketingu jako rozpowszechnianie dezinformacji, aby przekonać konsumentów do tego, że dana organizacja działa społecznie odpowiedzialnie w zakresie środowiska naturalnego. Problem ten pojawia się coraz częściej na różnych rynkach, a badań na ten temat jest stosunkowo niedużo, szczególnie w zakresie reakcji konsumentów.

Wyniki badań rynkowych wskazują, że zjawisko dezinformacji konsumentów, niezależnie czego by dotyczyło, narusza ich pozycję przetargową i prowadzi do błędnych, wynikających $\mathrm{z}$ nieświadomości, zachowań na rynku. Z tego względu, poznanie przez konsumentów mechanizmów unikania wpadnięcia w pułapkę greenwashing stanowi cenny fragment wiedzy ${ }^{1}$.

Ostatnia dekada charakteryzuje się rozwojem na rynku produktów i usług ekologicznych. W 2009 roku obroty na nim wyniosły 230 miliardów dolarów a 2015 roku szacowany był na około 850 miliardów dolarów. Wobec tego, firmy coraz częściej korzystają z zielonych praktyk, aby zwiększyć swoje korzyści. Szacunkowe wyniki informuja, że rynek zielonej reklamy wzrósł ponad 10 krotnie w ostatnich 20 latach. Coraz więcej firm, podążając tym nurtem, angażuje się w praktykowanie greenwashing,

\footnotetext{
${ }^{1}$ Wyniki badań własnych, 2026-2018,
} 
wprowadzając konsumentów w błąd. Konsekwencją tych działań może być spadek zaufania konsumentów do produktów i usług ekologicznych w ogóle ${ }^{2}$.

Działania z obszaru greenwashing wykorzystują asymetrię informacyjną i wprowadzają kupujących w błąd ${ }^{3}$ (rys. 1).

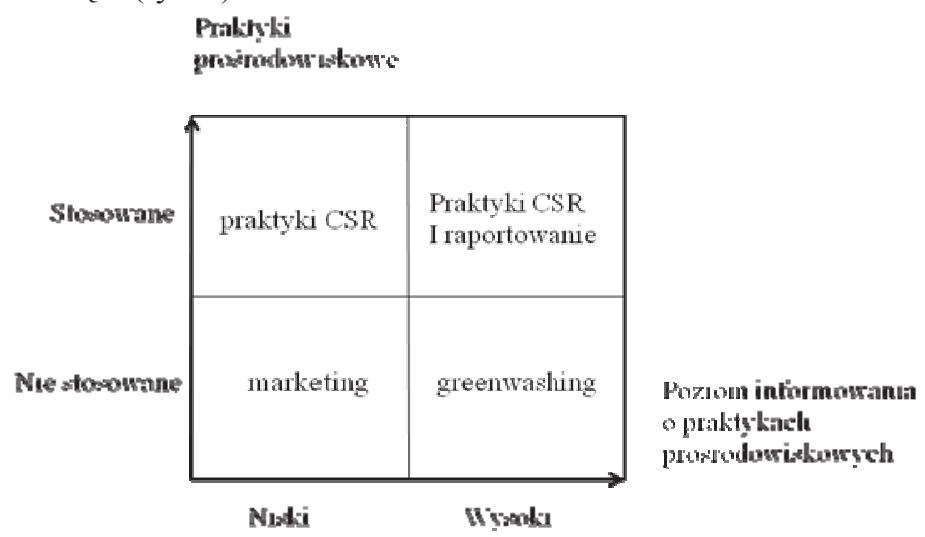

Rysunek 1. Klasyfikacja praktyk firm pod względem działań i komunikacji o odpowiedzialności środowiskowej

Źródło: opracowanie własne.

Według analizy danych raportu Terrachiose, aż 95\% przypadków w USA, przeanalizowane informacje o produktach były nieprawidłowe ${ }^{4}$. Z tego względu można zjawisko greenwashing uznać za powszechne. Firmy decydują się na tego typu działania ze względu na to, że przynoszą one oczekiwane efekty w postaci sympatii i lojalności konsumentów. Tworzenie przyjaznego środowisku naturalnemu wizerunku, czy produktu, napotyka się coraz częściej z silną aprobatą konsumentów (Jakubczak, 2015), która przekłada się wprost na zyski firm praktykujących taki proceder.

Celem artykułu jest analiza strategii greenwashing stosowanych przez sklepy dyskontowe $\mathrm{w}$ ofercie produktów spożywczych oraz na opakowaniach przez producentów tych produktów.

Badania rozpoczęto od przedstawienia definicji i podejścia do greenwashing $\mathrm{w}$ literaturze o marketingu i bieżących badaniach umieszczonych $\mathrm{w}$ czasopismach fachowych. Kolejnym obszarem badawczym były strategie greenwashing, zaobserwowane w sześciu podmiotach badawczych, reprezentujących dwie wiodące na rynku polskim sieci dyskontowe. Wybór obiektów badawczych miał charakter celowoprzypadkowy. Celowo wybrano dwie wiodące na rynku polskim sieci dyskontowe, a następnie, w sposób przypadkowy, dla każdej z nich wytypowano po trzy sklepy. W wybranych obiektach prowadzono obserwację oraz dokonywano dokumentacji

\footnotetext{
${ }^{2}$ M.A. Delamas, V.C. Burbano: The Drivers of Greenwashing, CMR.BERKELEY.EDU, Vol. 54, No.1/2011, s. 64-87.

${ }^{3}$ A. Jakubczak, M. Gotowska, Greenwashing on food market in opinion of young consumers from some European countries, MIC 2018, Ekonomska istrazivanja - Economic Research, w recenzji.

${ }^{4}$ TerraChoice, Greenwashing Report 2010: The Seven Sins of Greenwashing: Environmental Claims in Consumer Markets. 2010, http://sinsofgreenwashing.com/findings/index.html (23.03.2018).
} 
fotograficznej ${ }^{5}$. Następnie zdjęcia poddano analizie i na tej podstawie opracowano wyniki w ujęciu tabelarycznym i opisowym.

\section{Strategie greenwashing}

W literaturze przedmiotu nie ma dotychczas ustalonej jednej spójnej definicji greenwashing, jednak badania prowadzone $\mathrm{w}$ tym zakresie umożliwiły określenie pewnych wyróżniających cech dla tego procederu. Po pierwsze, firmy stosujące greenwasin,g robią to, bo chcą poprawić swój wizerunek ${ }^{6}$. Dążą do uzyskania image formy ekologicznej lub przyjaznej dla środowiska naturalnego. Spodziewanym efektem tego działania ma być wzrost akceptacji w otoczeniu organizacji np. wśród klientów, potencjalnych pracowników, inwestorów, czy kontrahentów ${ }^{7}$. Po drugie, niestety, tworzenie wizerunku firmy, chcącej uchodzić za przyjazną w swojej działalności, nie zawsze idzie $\mathrm{w}$ parze $\mathrm{z}$ jej wizerunkiem rzeczywistym. Dzieje się tak, bo firmy intencjonalnie wprowadzają otoczenie w błąd ${ }^{8}$. Po trzecie, często trudno jest grupom docelowym zweryfikować podawane przez te firmy informacje w sposób merytoryczny. Informacje ze strony firm o ich działalności są ograniczone, niekompletne a nawet nadawane podprogowo'.

Typowe strategie greenwashing przedstawiono na rysunku 2. Odnoszą się one do dwóch poziomów: przedsiębiorstwa - przedstawianie praktyk środowiskowych oraz produktu - przedstawianie korzyści dla środowiska wynikających z cech produktu lub usługi $1^{10}$.

\footnotetext{
${ }^{5}$ Autor wszystkich zdjęć: Anna Jakubczak

${ }^{6}$ M.A. Delamas, V.C. Burbano, The Drivers of ... s. 64-87.

${ }^{7}$ F. Bowen, J. A. Aragon-Correa, Greenwashing in corporate environmentalism research and practice: The importance of what we say and do. Organization \& Environment, No. 27/2014, s. 107-112.

${ }^{8}$ T. P. Lyon, J. W.Maxwell, Greenwash: Corporate environmental disclosure under threat of audit. Journal of Economics \& Management Strategy, No. 20(1)/2011, s. 3-41.

${ }^{9}$ Y. S. Chen, C. H. Chang. Greenwash and green trust: The mediation effects of green consumer confusion and green perceived risk. Journal of Business Ethics, No. 114/2013, s. 489-500.

${ }^{10}$ TerraChoice Group, Inc. [op. cit.] definiuje greenwashing jako "the act of misleading consumers regarding the environmental practices of a company or the environmental benefits of a product or service."
} 


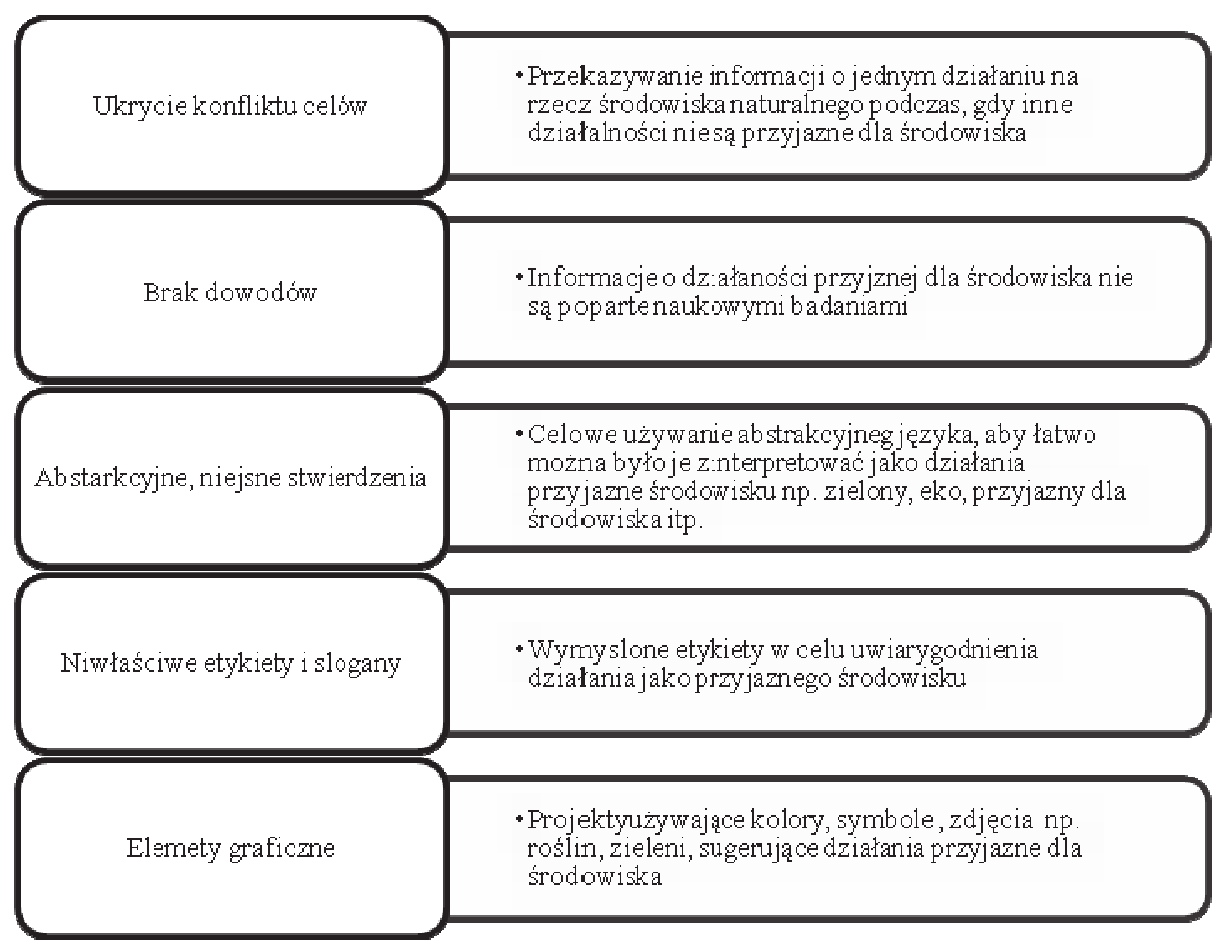

Rysunek 2. Przykłady strategii greenwashigu

Źródło: opracowanie własne na podstawie: K.M. Griese, K. Werner, J. Hogg,, Avoiding Greenwashing in Event Marketing: An Exploration of Concepts, Literature and Methods. Journal of Management and Sustainability; Vol. 7, No. 4/2017, s. 4.

Po czwarte, greenwashing charakteryzuje się tym, że firma sugeruje swoją zasobooszczędność, chociaż nie ma to potwierdzenia w realnych działaniach. Ostatnią cechą greenwashing jest przekazywanie tych informacji o rzekomych działaniach, które dotyczą znanych i szeroko omawianych w przestrzeni publicznej problemów, związanych $\mathrm{z}$ zagrożeniami środowiska np. emisja CO2, gospodarka odpadami komunalnymi, natomiast ukrywania lub pomija w informowaniu te działania, w których firma przyczynia się do pogorszenie kondycji środowiska ${ }^{11}$.

Grupa TerraChoice wyróżnia siedem elementów składających się na praktyki firm stosujących greenwashing: ukryty kompromis - czyli sugerowanie, że produkt, działanie, czy wydarzenie jest zielone w oparciu o nieuzasadnione cechy; kłamstwo - fałszywe orzeczenia środowiskowe; bez dowodu; nieokreśloność; nieistotność; pomniejszanie zła i fałszywe etykiety ${ }^{12}$.

\footnotetext{
${ }^{11}$ M. J. Polonsky, Transformative green marketing: Impediments and opportunities, Journal of Business Research, No. 64(12)/2010, s. 1311-1319.

${ }^{12}$ TerraChoice, Greenwashing...,
} 


\section{Charakterystyka produktów organicznych - wybrane aspekty}

Rynek produktów ekologicznych (organicznych) rośnie w Europie i w Polsce, jak wynika z danych Instytutu Badań na rzecz Rolnictwa Ekologicznego. Konsumenci cenią tego typu produkty za walory smakowe i zdrowotne. Ich produkcja łączy się ze zmniejszonym stosowaniem nawozów sztucznych, obniżeniem emisji gazów cieplarnianych. System produkcji ekologicznej sprzyja rozwojowi lokalnych producentów, także poprzez różnicowanie działalności na obszarach wiejskich, tworzeniu miejsc pracy, daje gwarancję lepszego bardziej humanitarnego traktowania zwierząt hodowlanych ${ }^{13}, 14,15,16$.

Wyniki badań wskazują, że konsumenci przy zakupie produktów ekologicznych kierują się kryteriami związanymi z ochroną środowiska. Liczne skandale spożywcze przyczyniły się do tego, że wybierane są chętnie produkty naturalne. Wzrastający popyt na edo-produkty jest związany $\mathrm{z}$ głębszymi zmianami we współczesnym modelu konsumpcji. Obecny trend można nazwać green consumerism. Trend ten można scharakteryzować jako postępowanie konsumentów dążące do zachowania możliwości konsumpcji przez przyszłe pokolenia, przejawia się on w unikaniu produktów niebezpiecznych dla zdrowia konsumenta i jego otoczenia oraz wytwarzających szkody $\mathrm{w}$ środowisku naturalnym poprzez proces produkcji, używania oraz $\mathrm{w}$ fazie pokonsumpcyjnej a także zużywających nieproporcjonalnie dużo zasobów, czy przyczyniają się do niepotrzebnego marnotrawstwa np. przez obfite opakowania, nadmiar cech lub zbyt krótki okres przydatności do spożycia ${ }^{17}$.

Rozporządzanie Komisji Wspólnoty Europejskiej wskazuje jednoznacznie, że żywność może być oznakowana jako "ekologiczna" w przypadku, gdy co najmniej 95\% składników pochodzenia rolniczego jest wyprodukowana w sposób ekologiczny. Jednym $\mathrm{z}$ podstawowych założeń rolnictwa organicznego jest eliminacja $\mathrm{z}$ zastosowania nawozów sztucznych, syntetycznych pestycydów, dodatków a także polepszaczy i konserwantów ${ }^{18}$.

\section{Analiza strategii greenwashing w sieciach dyskontowych}

Analizę strategii greenwashing przeprowadzono łącznie w 6 sklepach, z których każde 3 reprezentowały inną sieć dyskontową. Obiekty dla celów analizy nazwano A: A1, A2, A3 i B: B1, B2, B3. Badano następujące aspekty dotyczące produktów

\footnotetext{
${ }^{13}$ K. Wasilik, Rolnictwo ekologiczne i rynek eko-produktów w Polsce na tle innych krajów europejskich, Handel Wewnętrzny Nr 3 (350)/2014, s. 157-168.

${ }^{14}$ B. Klepacki, Organizacyjne i ekonomiczne uwarunkowania postępu technologicznego w gospodarstwach indywidualnych (na przykładzie produkcji roślinnej). Rozprawy Naukowe i Monografie. SGGW-AR $124 / 1990$, s. 88.

${ }^{15}$ M. Adamowicz, M. Zwolińska -Ligaj, Koncepcja wielofunkcyjności jako element zrównoważonego rozwoju obszarów wiejskich, www.wne.sggw.pl/czasopisma/pdf/PEFIM nr 512009 s11.pdf (28.03.2018), s. 11-38.

${ }^{16} \mathrm{M}$. Adamowicz. Zrównoważony i wielofunkcyjny rozwój rolnictwa a agronomia, Annales UMCS Setion E 60/2005, s. 71-91.

${ }^{17}$ L. Witek, Zachowania konsumentów na rynku produktów ekologicznych w Polsce i innych krajach Unii Europejskiej, Handel Wewnętrzny Nr 1(354)/2014, s. 281-290.

${ }^{18}$ J. Gadomska, T. Sadowski, M. Buczkowska, Ekologiczna Żywność jako czynnik sprzyjający zdrowiu.

Problemy Higieny i Epidemiologii, Nr 95(3)/2014, s. 556-560.
} 
żywnościowych w opakowaniach oferowanych w tych sklepach w okresie pomiędzy 20 lutym a 10 marca 2018:

1. Występowanie produktów ekologicznych oraz Fit lub Bio (organicznych) oraz ich rodzaj;

2. Liczba produktów ekologicznych oraz Fit lub Bio;

3. Liczba produktów z oznaczeniami ekologicznymi certyfikowanymi i z oznaczeniami sugerującymi żywność ekologiczną oraz Fit lub Bio;

4. Informacje na opakowaniach produktów oznaczonych jako ekologiczne oraz Fit lub Bio;

5. Skład produktów oznaczonych jako ekologiczne oraz Fit lub Bio;

6. Usytuowanie i sposób eksponowania produktów oznaczonych jako ekologiczne oraz Fit lub Bio;

7. Występowanie świeżych warzyw i owoców typowo sezonowych w Polsce np. truskawki, groszek itp. poza sezonem.

Szczegółowe wyniki zamieszczono w tabelach i na rysunkach.

W tabeli pierwszej znajdują się wyniki dotyczące badań, głównie w aspekcie ilościowym. W obu rodzajach placówek handlowych zanotowano występowanie produktów organicznych. W sieci A możliwych do zbadania i spełniających przyjęte kryteria było 28 produktów, a w sieci B - 16. Liczba produktów organicznych w ofercie była większa w sieci A niż w sieci B ponad trzykrotnie i obejmowała $60 \%$ przebadanych w sieci A towarów. Sieć B posiadała w ofercie stosunkowo mniejszy udział produktów posiadających certyfikaty potwierdzające ich organiczne pochodzenie( $31 \%)$. W porównaniu do sklepów sieci A na półkach sieci B znajdował się większy odsetek produktów "udających" produkty organiczne, było ich prawie $70 \%$ podczas gdy w sieci A niespełna 40\% (tab. 1).

Tabela 1. Wyniki badań w sklepach dwóch różnych sieci dyskontowych

\begin{tabular}{|c|c|c|c|}
\hline Lp. & Zagadnienie/obiekt & A & B \\
\hline 1. & $\begin{array}{l}\text { Występowanie produktów oznaczonych jako Eko, Fit lub Bio np. symbol, kolor } \\
\text { opakowania sugerujący ekoprodukt }\end{array}$ & tak & tak \\
\hline 3. & Liczba produktów zbadanych & 28 & 16 \\
\hline 4. & $\begin{array}{l}\text { Liczba produktów z oznaczeniami ekologicznymi certyfikowanymi oraz udział w ogóle i } \\
\mathrm{w}(\%)\end{array}$ & $\begin{array}{c}17 \\
(60)\end{array}$ & $\begin{array}{c}5 \\
(31)\end{array}$ \\
\hline 5. & $\begin{array}{l}\text { Liczba produktów oznaczonych etykietami sugerującymi je jako Eko, Fit lub Bio } \\
\text { oraz/lub kolorem zielonym lub brązowym na opakowaniu oraz bezpośrednim } \\
\text { sąsiedztwem z produktami organicznymi w ogóle }(\%)\end{array}$ & $\begin{array}{c}11 \\
(39)\end{array}$ & $\begin{array}{c}11 \\
(69)\end{array}$ \\
\hline
\end{tabular}

Źródło: opracowanie własne na podstawie badań.

Asortyment przeanalizowanych produktów był bardziej urozmaicony w podmiotach sieci A. Zanotowano tam ponad 20 rodzajów produktów. Największa liczba produktów, w obu sieciach, obejmowała produkty zbożowe, takie jak musli, płatki zbożowe czy chleb oraz makaron. Była tam też kawa, oliwa, suszone warzywa lub owoce, soki i surówki (tab. 2). 
Tabela 2. Rodzaj produktów oznaczonych jako Eko, Fit lub Bio

\begin{tabular}{|ll|l|}
\hline & A & \multicolumn{1}{c|}{ B } \\
- płatki śniadaniowe BIO, & - oliwa BIO, & - owoce suszone BIO: figa i \\
- musli cruchy BIO, & - olej kokosowy BIO, & morele, żurawina, \\
- musli, płatki pełnoziarniste & - produkty sypkie: soja, kasza, & - musli, musli Fit \\
- musli owocowe, & - ksylitol, & - płatki śniadaniowe, Fit, crunchy \\
- owsianka, & - kawa BIO, & - suszone ziemniaczane, \\
- płatki owsiane BIO, & - soki BIO, & - smoothie truskawka, porzeczka \\
- płatki jaglane Vit & - syrop klonowy BIO, syrop z & i cytryna \\
- płatki pszenno-ryżowe Vit & agavy BIO, & \\
- chleb żytni razowy BIO, & - makaron BIO, \\
- przekąska - suszone jabłko z & - baton owocowy, & \\
cynamonem, & - dżem BIO, & \\
- mus owocowy BIO, & - kapusta kiszona BIO, ogórki & \\
- chipsy warzywne BIO, & kiszone BIO, surówka z kapusty & \\
& BIO; & \\
\hline
\end{tabular}

Źródło: opracowanie własne na podstawie badań.

W obu sieciach produkty "udające" towary organiczne zawierały różnego rodzaju składniki, które mogą być uważane za szkodliwe dla zdrowia i powodujące, że nie mogą one być uznane za produkty organiczne. Były to najczęściej substancje konserwujące lub poprawiające smak. Analizując skład stwierdzono również odstępstwa od sugerowanego na opakowaniach składu (tab. 3).

Tabela 3. Skład wybranych produktów oznaczonych jako Eko, Fit lub Bio

\begin{tabular}{|l|l|}
\hline \multicolumn{1}{|c|}{ A } & \multicolumn{1}{|c|}{ B } \\
Np.: & Np.: \\
- baton z truskawkami: sorbinian potasu, olej & - suszona żurawina w bezpośrednim sąsiedztwie moreli \\
palmowy, dwutlenek siarki, tylko 1,5\% & i fig suszonych BIO, która zawiera 34\% cukru; \\
liofilizowanych truskawek; & - suszone morele: dwutlenek siarki \\
- musli owocowe: cukier; & - płatki śniadaniowe - pełne ziarno, chrunchy zawierają: \\
- musli BIO: cukier z rolnictwa ekologicznego; & cukier, syrop cukru inwertowanego, melisę cukru, syrop \\
- musli śniadaniowe: cukier, dwutlenek siarki, olej & glukozowy, mieszaninę tokofenoli, siarczyn sodu; \\
palmowy, weglan sodu, cukier skarmelizowany; & - płatki Fit - cukier 16\%, utwardzony tłuszcz palmowy, \\
- owsianka: cukier trzcinowy 14,3\% & syrop glukozowy dwutlenek siarki, fosforan sodu, \\
- płatki jaglane, pszeno-ryżowe: cukier 7\%, syrop & węglan sodu; \\
glukozowy, ekstrakt słodu, mono- i diglicerydy & - suszone owoce - cukier, kwas cytrynowy, kwas \\
kwasów tłuszczowych, sól, kwas cytrynowy - & askorbinowy \\
płatki pełnoziarniste: cukier 9,3\%, syrop & chipsy ziemniaczane: śmietanka w proszku, cukier \\
glukozowy, mono- i diglicerydy kwasów & - smoothie: zawiera większość składników nie \\
tłuszczowych, mieszanina tokoferoli, aromat & podanych w nazwie: przecier bananowy suszony, jabłko \\
& suszone z przecierem bananowym, burak suszony, \\
\hline Źródło: opracowanie własne na podstawie badań. & zagęszczony sok z granatu suszony; \\
\hline
\end{tabular}

W jednej i drugiej sieci znajdowały się produkty z oznaczeniami sugerującymi pochodzenie organiczne towarów, ich prozdrowotne działanie, dużą zawartość korzystnych dla zdrowia składników, brak składników szkodliwych dla zdrowia, naturalność, prawdziwość i wysoką jakość (tab. 4). Jednak część tych informacji mogłaby zostać uznana za fałsz, ponieważ wymienione w tabeli 1 produkty tak oznaczone, nie posiadały certyfikatów, a przede wszystkim posiadały substancje szkodliwe dla zdrowia lub ich skład nie był zgodny $\mathrm{z}$ sugestiami zawartymi na opakowaniu. 
Oznakowania graficzne oraz użyta kolorystyka na produktach certyfikowanych BIO znajduje się na rysunku 3 od numeru 1 do 3 . Pozostałe elementy grafiki zostały sfotografowane na opakowaniach produktów "udających" produkty organiczne. Należy zwrócić uwagę, że na opakowaniach tych produktów dominują motywy roślinne: liść, kłos oraz kolory różnych odcieni zieleni i brązu, czyli kolory natury. Cześć tych elementów graficznych wprost naśladuje symbolikę znajdującą się na towarach certyfikowanych np. 5, 14 .

Tabela 4. Informacje na opakowaniach produktów oznaczonych jako Eko, Fit lub Bio

\begin{tabular}{|c|}
\hline Naturalne źródło ... \\
Z pełnego ziarna ... \\
Pełnoziarniste \\
Źródło błonnika ... \\
Gluten free \\
Nowa jakość \\
Zawartość witamin, 8 witamin + żelazo \\
Natura ... \\
Z dodatkiem superfoods z owoców i warzyw \\
Pubstancji konserwujących, bez dodatku cukru, bez dodatku aromatów \\
Prawdziwe... Dobre... \\
Bio \\
Naturalnie na zdrowie \\
Organic \\
Pomaga w prawidłowym funkcjonowaniu układu pokarmowego \\
Pomaga w obniżeniu cholesterolu we krwi \\
Bez dodatku cukrów
\end{tabular}

Źródło: opracowanie własne na podstawie badań.

W ofercie sieci A znalazły się, w marcu, produkty sezonowe jak truskawki, borówki, czy maliny. W sieci B produktem takim był groszek cukrowy w strączkach. Jasne jest, że towary te pochodzą $z$ importu i wymagały transportu z daleka. A przecież jedną z zasad zrównoważonego handlu jest dostarczanie konsumentom produktów z zachowaniem zasad efektywności nie tylko ekonomicznej ale także ekologicznej.
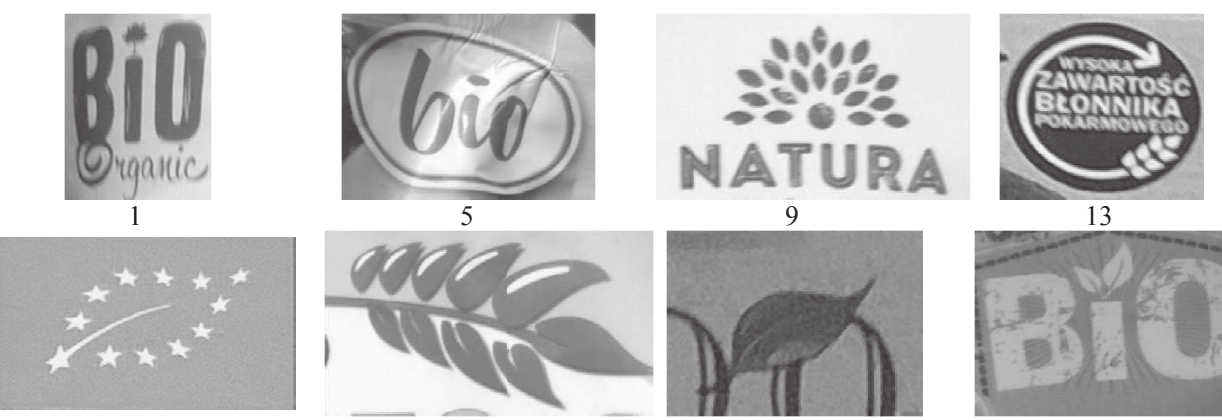

2

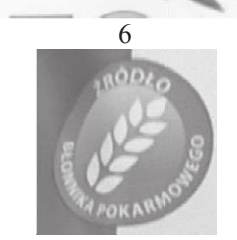

10
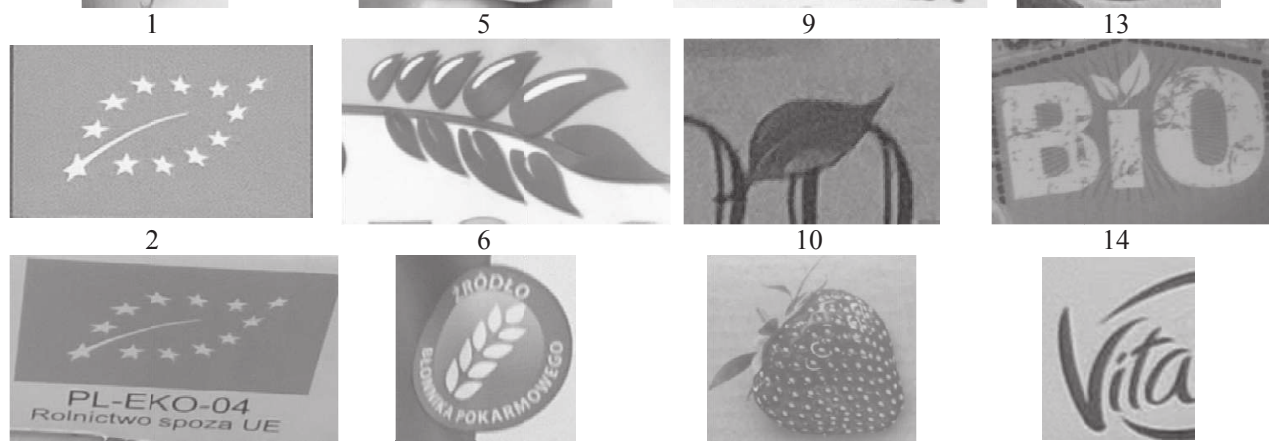

14

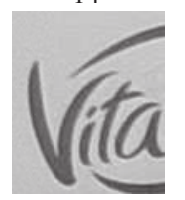



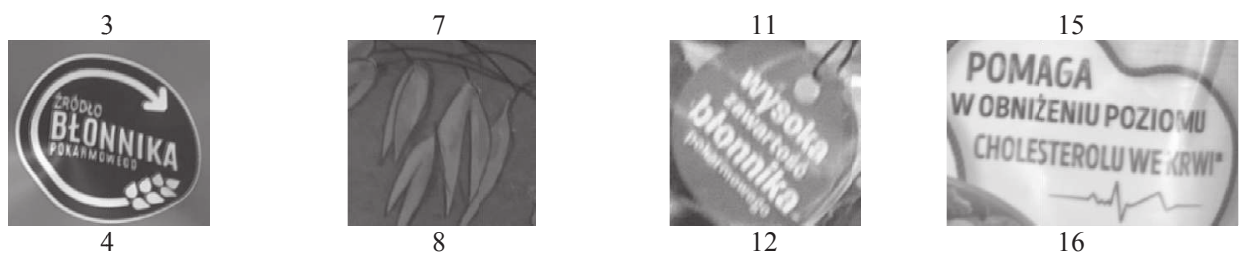

Rysunek 3. Symbole na opakowaniach produktów oznaczonych jako Eko, Fit lub Bio Źródło: opracowanie własne na podstawie badań.

A

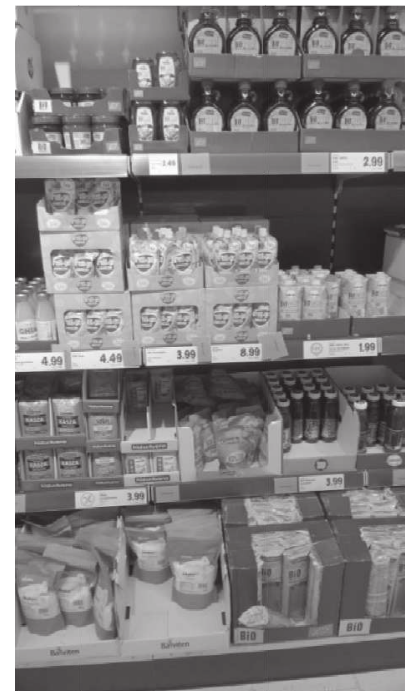

Skoncentrowane, większa liczba produktów Bio na jednym regale
B

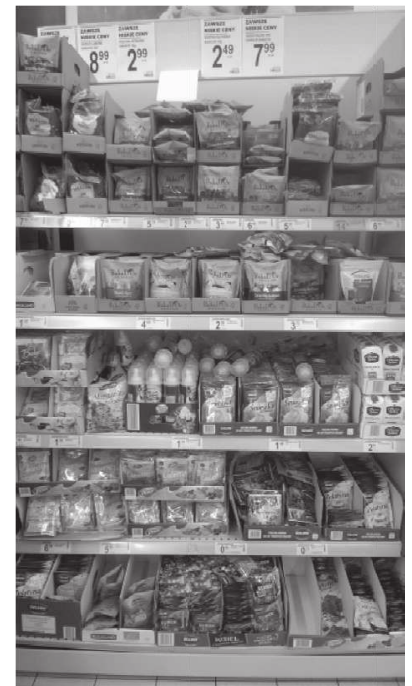

Rozproszone, wmieszane, produkty Bio razem z produktami podobnego asortymentu

Rysunek 4. Usytuowanie i sposób eksponowania produktów oznaczonych jako Eko, Fit lub Bio Źródło: opracowanie własne na podstawie badań.

W obu sieciach zaobserwowano zróżnicowane podejście do eksponowania produktów organicznych. W sieci A produkty te umieszczane były w większości na osobnym regale. Kilka produktów organicznych, certyfikowanych znajdowała się w różnych miejscach na sali sprzedaży, a obok pojedynczych produktów tego typu znajdowały się zwykle także towary "symulujące" pochodzenie organiczne. W sieci B tendencja $\mathrm{w}$ rozproszeniu towarów organicznych była znacznie większa. właściwie nie było dla nich osobnego regału, gdzie występowały by w dominacji (rys. 4).

Często, jak wynika $\mathrm{z}$ przeprowadzonych obserwacji, obok produktów BIO umieszczane są produkty podobnego rodzaju, nie posiadające certyfikatów, ale wygląd ich opakowań może wprowadzać kupujących w błąd. Na rysunku 5 zauważyć można, że musli BIO, posiadające oznaczenia certyfikowania, jest $\mathrm{w}$ bliskim sąsiedztwie innych rodzajów musli, które tego certyfikatu nie posiadają. Na ich opakowaniach dominuje kolor zielony lub opakowania są przeźroczyste i przedstawiają zawartość widoczną gołym okiem. Natomiast skład zawartości tych opakowań znacząco różni się od składu produktów oznaczonych znakiem certyfikowanym. 


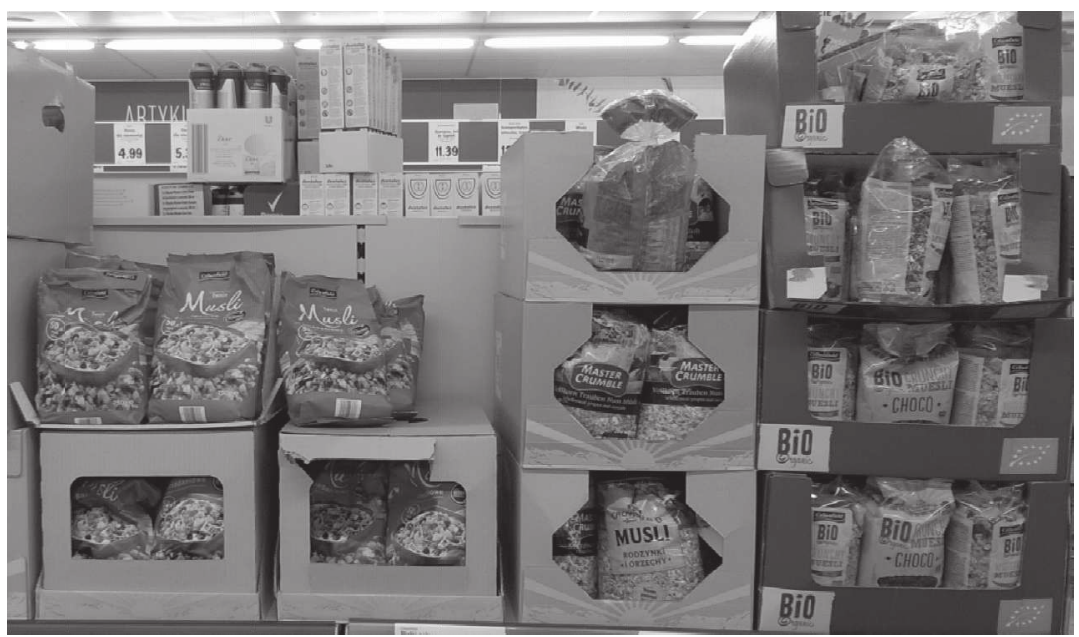

Rysunek 5. Usytuowanie produktów Bio i nie posiadających certyfikatu w obiekcie A3 Źródło: opracowanie własne na podstawie badań.

\section{Podsumowanie}

Przeprowadzone badanie i uzyskane wyniki pozwalają zauważyć, że sprzedawcy w analizowanych jednostkach handlowych nie biorą odpowiedzialności za sprzedawane produkty w zakresie rzetelnego informowania konsumentów. Najczęściej popełniane działania dezinformacyjne, w tym przypadku, to umieszczanie produktów BIO, czy to w opakowaniach jednostkowych czy zbiorczych, w różnych miejscach sklepu w towarzystwie podobnego asortymentu produktów symulujących wyglądem opakowań produkty BIO. Kolejną praktyką jest brak wydzielonego regału na produkty organiczne. Oba te działania mogą być odebrane jako celowe wprowadzanie konsumentów w błąd.

Wielu producentów towarów eksponowanych w badanych sklepach dyskontowych stosuje strategie greenwashing. Najczęściej umieszczane są elementy graficzne oraz kolorystyka opakowania sugerująca prozdrowotną zawartość, wyższą jakość, naturalność. Producenci, $\mathrm{w}$ ten sposób, w większej mierze korzystają z braku odpowiedzialności sprzedawców za prawidłowe informowanie konsumentów.

Z powyższego wynika, że konsumenci mają utrudnioną sytuację podejmowania decyzji zakupowych zarówno ze strony producentów jak i handlowców. Z tego względu, aby zadbać o swoje dobro, muszą oni podejmować większy wysiłek podczas dokonywania zakupów przeznaczony na czytanie składu na opakowaniu, czy też wykazać większą koncentrację w rozpoznawaniu pożądanej kategorii produktów po etykietach.

\section{Bibliografia}

Adamowicz M., Zrównoważony i wielofunkcyjny rozwój rolnictwa a agronomia, Annales UMCS Setion E 60/2005.

Adamowicz M., Zwolińska -Ligaj M., Koncepcja wielofunkcyjności jako element zrównoważonego rozwoju obszarów wiejskich, www.wne.sggw.pl/czasopisma/pdf/ PEFIM_nr_51_2009_s11.pdf. 
Bowen F., Aragon-Correa J. A.: Greenwashing in corporate environmentalism research and practice: The importance of what we say and do. Organization \& Environment, 27/2014.

Chen Y. S., Chang C. H.: Greenwash and green trust: The mediation effects of green consumer confusion and green perceived risk. Journal of Business Ethics, 114/2013.

Delamas M.A., Burbano V.C., The Drivers of Greenwashing, CMR.BERKELEY.EDU, 54, $1 / 2011$.

Gadomska J., Sadowski T., Buczkowska M.: Ekologiczna Żywność jako czynnik sprzyjający zdrowiu. Problemy Higieny i Epidemiologii, 95(3)/2014.

Griese K.M., Werner K., Hogg J., Avoiding Greenwashing in Event Marketing: An Exploration of Concepts, Literature and Methods. Journal of Management and Sustainability, 7(4)/2017.

Jakubczak A., Gotowska M.: Greenwashing on food market in opinion of young consumers from some European countries, MIC 2018, Ekonomska istrazivanja - Economic Research, w recenzji.

Klepacki B., Organizacyjne i ekonomiczne uwarunkowania postępu technologicznego w gospodarstwach indywidualnych (na przykładzie produkcji roślinnej), Rozprawy Naukowe i Monografie. SGGW-AR 124/1990.

Lyon T. P., Maxwell J. W.: Greenwash: Corporate environmental disclosure under threat of audit. Journal of Economics \& Management Strategy, 20(1)/2011.

Polonsky M. J.: Transformative green marketing: Impediments and opportunities, Journal of Business Research, 64(12)/2010.

TerraChoice: Greenwashing Report 2010: The Seven Sins of Greenwashing: Environmental Claims in Consumer Markets. 2010, http://sinsofgreenwashing.com/findings/index.html (23.03.2018).

Wasilik K.: Rolnictwo ekologiczne i rynek eko-produktów w Polsce na tle innych krajów europejskich, Handel Wewnętrzny 3 (350)/2014.

Witek L.: Zachowania konsumentów na rynku produktów ekologicznych w Polsce i innych krajach Unii Europejskiej, Handel Wewnętrzny 1(354)/2014.

\section{Summary}

The problem raised in the article is the phenomenon of greenwashing increasingly used by business to introduce consumers into a misconception about the image of a company or product as environmentally friendly. The aim of the article is to analyze greenwashing strategies used by discount stores in the offer of food products in packaging and by producers of these products. Several dozen organic and organic "pretending" food products were analyzed in two popular discount chains in Poland. The analysis of the results confirms that in selected networks irresponsibly social practices favoring the use of greenwashing strategies are applied.

Key words: greenwasing, corporate social responsibility, consumer social responsibility, green consumerism

\section{Informacje o autorze:}

\section{Dr inż. Anna Jakubczak}

Uniwersytet Technologiczno-Przyrodniczy w Bydgoszczy

Wydział Zarządzania

im. J.J. Śniadeckich w Bydgoszczy

ul. Fordońska 430

85-790 Bydgoszcz

e-mail: ajakubczak@utp.edu.pl

ORCID: 0000-0001-9140-8658 